\title{
The interruptive effect of pain on attention
}

Citation for published version (APA):

Vancleef, L. M. G., \& Peters, M. L. (2006). The interruptive effect of pain on attention. The Journal of Pain, 7(1), 21-22. https://doi.org/10.1016/j.jpain.2005.11.003

Document status and date:

Published: 01/01/2006

DOI:

10.1016/j.jpain.2005.11.003

Document Version:

Publisher's PDF, also known as Version of record

Document license:

Taverne

Please check the document version of this publication:

- A submitted manuscript is the version of the article upon submission and before peer-review. There can be important differences between the submitted version and the official published version of record.

People interested in the research are advised to contact the author for the final version of the publication, or visit the DOI to the publisher's website.

- The final author version and the galley proof are versions of the publication after peer review.

- The final published version features the final layout of the paper including the volume, issue and page numbers.

Link to publication

\footnotetext{
General rights rights.

- You may freely distribute the URL identifying the publication in the public portal. please follow below link for the End User Agreement:

www.umlib.nl/taverne-license

Take down policy

If you believe that this document breaches copyright please contact us at:

repository@maastrichtuniversity.nl

providing details and we will investigate your claim.
}

Copyright and moral rights for the publications made accessible in the public portal are retained by the authors and/or other copyright owners and it is a condition of accessing publications that users recognise and abide by the legal requirements associated with these

- Users may download and print one copy of any publication from the public portal for the purpose of private study or research.

- You may not further distribute the material or use it for any profit-making activity or commercial gain

If the publication is distributed under the terms of Article $25 \mathrm{fa}$ of the Dutch Copyright Act, indicated by the "Taverne" license above, 


\title{
The Interruptive Effect of Pain on Attention
}

\author{
Linda M. G. Vancleef and Madelon L. Peters \\ Department of Medical, Clinical and Experimental Psychology, Maastricht University, Maastricht, \\ The Netherlands.
}

A large body of research has been conducted to study the relationship between pain and attention. It has been suggested that focusing attention on the performance of a high attention-demanding task can serve as a cognitive coping strategy to deal with pain, because all attentional resources will be devoted to task performance. On the other hand, evidence exists that pain can automatically enter focal attention, even when attention is being devoted to the performance of an attention-demanding task. Eccleston ${ }^{8}$ found that patients with high levels of selfreported pain performed worse on an attention-demanding task than those reporting lower pain levels, even though they were instructed to ignore their pain and focus on task performance.

When trying to explain the disturbing effect of pain on attention, it is important to consider the parameters that influence this effect. Several studies have used the primary task paradigm in their search for these parameters and revealed that besides the pain intensity, the novelty, unpredictability, and threat value of pain stimuli enlarge attentional disruption by pain. ${ }^{1-4,9,10}$ Thus, attentional interference by pain is larger when the pain stimulus is new and unfamiliar to the individual, or when the pain stimulus holds an implicit or explicit threat. But not only qualities of the pain stimulus itself determine the degree in which pain will interrupt attention. Individual characteristics may also moderate the attentional interference effect. Research found that persons who interpret pain as threatening, and persons who tend to catastrophize on the possible meaning and consequences of pain show an enhanced disruptive effect on attention. 5,6,9,10
We conclude that pain does interrupt attention, but that its intrusion into focal awareness is dependent upon several characteristics of the pain stimulus and the meaning that is assigned to it. The apparent contradictive outcomes of the study by Veldhuijzen et al $^{12}$ and our study ${ }^{11}$ should be interpreted in this light. We made use of an electrical pain stimulus of short duration that we administered randomly at several times during task performance. The imminent threat value of the pain stimulus was manipulated through instruction. Veldhuijzen et al used a more tonic pain stimulus (ie, cold pressor pain) that was continuously present during task performance. Previous studies, as well as or own study show that interruption by pain on attention is largest immediately after pain onset, after which the interruptive effect diminishes quickly. ${ }^{2-4,11}$ Immediately upon pain onset, an automatic orienting reflex occurs in which attention is devoted to the pain, and a fast evaluation of the meaning and gravity of the pain is made. When the result of this evaluation reveals that the pain is not threatening, attention will be devoted again to the task and performance will no longer suffer.

In the study of Veldhuijzen et al, the pain stimulus may have lost its meaningfulness to the participants owing to its long duration, making it easier to distract from. Furthermore, Veldhuijzen et al did not include measures of individual variability between participants. We believe that both our study and previous studies demonstrate that attentional interference was enhanced in persons with high levels of pain catastrophizing, fear of pain, or somatic awareness. ${ }^{5-7,10,11}$

\section{References}

Address reprint requests to Linda Vancleef, Department of Medical, Clinical and Experimental Psychology, Maastricht University, P.O. Box 616,6200 MD Maastricht, The Netherlands. E-mail: L.Vancleef@ dmkep.unimaas.nl

$1526-5900 / \$ 32.00$

(c) 2006 by the American Pain Society

doi:10.1016/j.jpain.2005.11.003

1. Crombez G, Baeyens F, Eelen P: Sensory and temporal information about impending pain: The influence of predictability on pain. Behav Res Ther 32:611-622, 1994

2. Crombez G, Eccleston C, Baeyens F, Eelen P: The disruptive nature of pain: An experimental investigation. Behav Res Ther 34:911-918, 1996 
3. Crombez G, Eccleston C, Baeyens F, Eelen P: Habituation and the interference of pain with task performance. Pain 70:149-154, 1997

4. Crombez G, Eccleston C, Baeyens F, Eelen P: Attentional disruption is enhanced by the threat of pain. Behav Res Ther 36:195-204, 1998

5. Crombez G, Eccleston C, Baeyens F, Eelen P: When somatic information threatens, catastrophic thinking enhances attentional interference. Pain 75:187-198, 1998

6. Crombez G, Eccleston C, Van den Broeck A, Van Houdenhove $B$, Goubert L: The effects of catastrophic thinking about pain on attentional interference by pain: No mediation of negative affectivity in healthy volunteers and in patients with low back pain. Pain Res Manage 7:31-39, 2002

7. Crombez G, Vlaeyen JW, Heuts PHTG, Lysens R: Fear of pain is more disabling than pain itself. Evidence on the role of pain-related fear in chronic back pain disability. Pain 80:329-340, 1999

8. Eccleston C: Chronic pain and attention: A cognitive approach. Br J Clin Psychol 33:535-547, 1994

9. Eccleston C, Crombez G: Pain demands attention: A cognitive-affective model of the interruptive function of pain Psychol Bull 125:356-366, 1999

10. Eccleston C, Crombez G, Aldrich S, Stannard C: Attention and somatic awareness in chronic pain. Pain 72:209-215, 1997

11. Vancleef LMG, Peters ML: Pain catastrophizing, but not injury/illness sensitivity or anxiety sensitivity, enhances attentional disruption by pain. J Pain 7:23-30, 2006

12. Veldhuijzen DS, Kenemans JL, Bruin de M, Olivier B, Volkerts ER: Pain and attention: Attentional disruption or distraction? J Pain 7:11-20, 2006 